DOI https://doi.org/10.36059/978-966-397-235-0-22

Хоббі Ю. С.,

кандидат юридичних наук, доцент, доцент кафедри державно-правових дисциплін

та публічного права

Донецького державного університет внутрішніх справ,

м. Маріуполь, Донецька область

\title{
СТАНОВЛЕННЯ ЧЕТВЕРТОГО ПОКОЛІННЯ ПРАВ ЛЮДИНИ: ПРОБЛЕМНІ АСПЕКТИ
}

Анотація. у статті аналізуються проблемні аспекти становлення та класифікації четвертого покоління прав людини. Висловлена думка, що класифікація за поколіннями прав людини $\epsilon$ недоречною, оскільки всі права взаємопов'язані й доповнюють одне одного, по суті, більшість із них є природними, а науковотехнічний прогрес їх модифікував і пристосував до реалій сьогодення. Тому пропонується застосовувати до деяких із них принцип динамічного й ефективного тлумачення, який використовується ЄСПЛ. Установлена неможливість надання правам четвертого покоління родової або класифікуючої назви, як, наприклад, солідарні права, через відсутність узгодженої позиції щодо їх переліку. Розглянуто різні класифікації четвертого покоління прав, на підставі чого встановлено, що одностайність науковців спостерігається щодо певних біологічних прав (право на смерть, зміну статі), тоді як сексуальні та віртуальні права визнаються не всіма. Підкреслюється, що нормативно-правова регламентація так званих біологічних прав можлива лише локально через складність досягнення консенсусу держав, що мають власні культурні й релігійні традиції.

\section{Вступ}

Принцип поваги до прав людини $\epsilon$ нині ключовим у глобалізованому світі, оскільки ця категорія виведена 3-під суто внутрішньої юрисдикції певної держави і $\epsilon$ надбанням усього міжнародного співтовариства. У різні історичні періоди ставлення до прав людини, загалом до необхідності їх захисту було неоднаковим, починаючи з їх ігнорування загалом і закінчуючи 
Права людини в Україні та у зарубіжних країнах: традиції та новації

пильною увагою до їх захисту із залученням відповідних міжнародних механізмів і процедур. Саме забезпечення принципу поваги прав людини поряд із демократією та верховенством права $\epsilon$ індикатором цивілізованої держави.

Права людини мають різну природу і $\epsilon$ мінливою категорією, оскільки постійно видозмінюються й еволюціонують відповідно до науково-технічного прогресу та розвитку суспільства. Тому в науковій літературі вони систематизовані в теорію «трьох поколінь прав людини» згідно з етапами історичного розвитку. Проте сьогодні значні досягнення у сфері медицини та біотехнологій зумовили розвиток нових прав, які деякі вчені відносять до нового або четвертого покоління прав людини. Це вимагає перегляду чинної доктрини прав людини.

Становлення четвертого покоління прав людини та й узагалі класифікація за поколіннями $\epsilon$ дуже дискусійним питанням, відносно якого серед науковців точаться дискусії. Прихильники виокремлення нового покоління прав спираються на досягнення науки й технологій, які подарували людству нові можливості, але чи доцільно ці можливості розглядати як нові права? Досі вони не дійшли згоди щодо родової назви цих прав і їх переліку. Послідовники іншої точки зору вважають, що поділ прав за поколіннями $є$ неправильним і вносить плутанину в усталену класичну систему прав людини.

Незважаючи на велику кількість наукових робіт у цій сфері, немає єдиної думки щодо родової назви, класифікації прав людина за етапами історичного розвитку та природи прав четвертого покоління, що ставить питання про необхідність їх систематизації та подальшого наукового дослідження, яке має відбуватися в кількох напрямах: чи є нові можливості, зумовлені науково-технічним прогресом, новими правами; критерії розмежування цих прав від інших поколінь; доцільність їх нормативно-правової регламентації.

\section{1. Проблеми становлення четвертого покоління прав людини}

Обсяг прав людини та їх перелік завжди пов'язаний із певним етапом розвитку суспільства. Практичного значення класифікація основних прав набуває при розробці конституцій та інших нормативно-правових актів будь-якої держави, оскільки це сприяє їх забезпеченню та реалізації й може полегшити 
Права людини в Україні та у зарубіжних країнах: традиції та новації

узгодженість міжнародного співтовариства стосовно змістового наповнення цих прав.

Використання різних критерії зумовлює існування різноманітних підходів до класифікації прав людини. На думку С. Бахіна, існує офіційна класифікація прав і свобод людини, яка передбачена міжнародними договорами, i неофіційна, або доктринальна, яку проводять науковці [1, с. 42].

Офіційну, чи міжнародно-правову класифікацію прав людини пов'язують із правами, закріпленими в Загальній декларації прав людини 1948 р., Міжнародних пактах 1966 р., Європейській конвенції про захист прав людини та основних свобод 1950 р., Європейській соціальній хартії 1961 р. На основі цього виділяють політичні, громадянські, економічні, соціальні, культурні права (очевидно, критерієм попереднього поділу є сфера людського життя). Згадана класифікація обгрунтовано піддається критиці за її недосконалість через неможливість однозначно віднести певне право до конкретної категорії.

До доктринальної належить і класифікація, розроблена французьким науковцем Карелом Васаком, в основі якої лежить генераційний підхід [2, с. 160]. Цей поділ прав на три покоління передбачає, що перше покоління становлять громадянські й політичні права (їх ще називають природними правами), які склалися в період буржуазних революції XVII-XVIII ст., друге покоління виникло як результат соціалістичних революції XIX ст. - соціально-економічні та культурні права (позитивні права, реалізація яких зумовлена певними зобов'язаннями держави), третє, яке хронологічно відноситься до другої половини XX ст. (права народів), - колективні права, або солідарні.

До першого покоління прав людини відносять традиційні ліберальні права і свободи, з яких, власне, і починаються права людини в їх сучасному розумінні: право на життя, свободу від тортур, поводження або покарання, що принижує людську гідність, право на свободу, право власності, свобода думки і совісті, слова тощо [3, с. 10].

До другого покоління прав, ідея яких з'являється на початку й формується після соціалістичних революцій, належать соціальні, економічні, культурні права, або скорочено соціально-економічні права, пов'язані з добробутом людини, рівнем і якістю її життя. Вони відображені в Загальній декларації прав людини й більш детально розроблені та викладені в Міжнародному пакті про 
економічні, соціальні і культурні права 1966 р.: право на працю, включаючи право на вибір сфери праці, право на відпочинок, на оплачувану відпустку, на освіту, медичне й соціальне забезпечення, соціальне страхування, захист материнства й дитинства тощо.

До колективних належать право народу на самовизначення, на мир, на самобутність, на достойне існування, на національну й міжнародну безпеку, на розвиток, право народу вільно розпоряджатися своїми природними ресурсами тощо [3, с. 10]. Більшість із них закріплено в Декларації ООН щодо питань навколишнього середовища (Стокгольмська декларація) 1972 р., Декларації ООН про виховання народів у дусі миру 1978 р., Декларації ООН про право народів на мир 1984 р., Африканській хартії прав людини і народів 1986 р., Декларації ООН Ріо-де-Жанейро щодо навколишнього середовища та розвитку 1992 р. тощо.

Варто зазначити, що природа колективних прав також $\epsilon$ дискусійною. Деякі науковці, наприклад, сам розробник цієї класифікації поколінь прав К. Васак до третього покоління відносив лише солідарні права, такі як право на розвиток, на мир, незалежність, самовизначення, територіальну цілісність, суверенітет, позбавлення від колоніальної залежності, на здорове навколишнє середовище, на спільне надбання людства, на комунікацію [4].

Інші вчені до цієї категорії також додають права окремих категорій осіб. Наприклад, С. Поленіна вважає, що третє покоління прав людини охоплює права (спеціальні права) тих категорій громадян (дітей, жінок, молоді, людей похилого віку, представників національних і расових меншин тощо), які через соціальні, політичні, фізіологічні й інші причини не мають рівних з іншими громадянами можливостей здійснення загальних для всіх людей прав і свобод, тому потребують підтримки й держави, і міжнародного співтовариства [5, с. 9].

Однак цей підхід розширеного тлумачення колективних прав може призвести до нівелювання ідеї природності прав, наданих кожній людині однаковою мірою незалежно від статі, раси, належності до будь-якої групи.

Така невизначеність суб'єкта цих прав і складність в окресленні осіб, що відповідальні за їх гарантування, зумовлена тим, що права третього покоління можуть бути реалізовані виключно завдяки спільним зусиллям усіх учасників публічних 
Права людини в Україні та у зарубіжних країнах: традиції та новації

відносин: фізичних осіб, юридичних осіб приватного та публічного права, держав і міжнародних організацій [6, с. 303].

Варто зазначити, що взагалі навколо класифікації К. Васака точаться дискусії стосовно змістового наповнення прав, що призводить до того, що одне й те саме право може належати до різних поколінь. Наприклад, право на мир, віднесене до третього покоління, обумовлює існування всіх інших прав (право на життя, свободу, соціально-культурні) і, відповідно, $\epsilon$ запорукою їх реалізації. Як слушно зауважив І.Б. Іванків, право на мир належить різним поколінням людства, а не певній особі або спільноті [7, с. 56].

Наприклад, такі українські науковці, як В. Мицик і В. Буткевич, уважають цю класифікацію умовно виведеною, яка не відповідає практиці прийняття міжнародних договорів з прав людини [8].

Н. Мушак також зауважує, що поділяти права людини суто на три покоління неправильно, оскільки сама по собі концепція прав людини $\epsilon$ динамічною, а такий поділ може послабити саму ідею фундаментальних права людини й увести додаткову плутанину в уже усталену систему прав людини [9, с. 29].

В умовах інтенсифікації глобалізаційних та інтеграційних процесів, науково-технічного прогресу в різних сферах суспільного життя перелік прав усе більш розширюється. Деякі вчені пропонують виділити четверте покоління прав людини.

Ще в 1996 р. О. Семітко запропонував виділити права четвертого покоління - біологічні, до яких він відніс права людини, пов'язані зі здійсненням абортів, евтаназії тощо [10, с. 207].

Інші автори називають їх соматичними правами (від грец. soma - тіло). Цей термін запропонував науковець В. Крусс, який визначає соматичні права як такі, що базуються на впевненості у праві людини самостійно розпоряджатися своїм тілом: здійснювати його модернізацію, реставрацію i навіть фундаментальну реконструкцію, змінювати функціональні можливості організму та розширювати їх техніко-агрегатними або медикаментозними засобами [11, с. 43].

Як ми бачимо, одностайності серед науковців щодо виокремлення й назви четвертого покоління прав, як, наприклад, солідарні права, немає, як i не існує їх чіткого, загальноприйнятого переліку. Наприклад, Ю. Дмитрієв до четвертого покоління прав відносить лише інформаційні права й технології [12, с. 125]. А. Венгеров називає четверте покоління 
правами людства: право на мир, на ядерну безпеку, космос, екологічні, інформаційні права тощо [13, с. 30]. А. Абашидзе, С. Глушкова виділяють соматичні права як права людини розпоряджатися своїм тілом (право на смерть, у сфері трансплантології, сексуальні та репродуктивні, на зміну статі) [14]. А. Ковлер, навпаки, відносить соматичні права до різновиду особистих (перше покоління) [15, с. 43].

Російський науковець С. Івентьєв узагалі пропонує виокремити ще й п’яте покоління прав людини - божественні та духовно-моральні права, до який відносить право на життя, на повагу до духовної та моральної гідності, на творчість, вибір, свободу совісті й віросповідання, духовну освіту та виховання, заборону катувань і нелюдського поводження тощо, покликані захистити людину від неконтрольованого науково-технічного прогресу [16, с. 200-201]. Але ця позиція здається не обгрунтованою, з огляду на те що всі ці права вже отримали своє правове закріплення й відносяться до першого покоління.

При виокремленні четвертого покоління прав людини не можна не звернути увагу на обмеженість критерію такого виділення, як час появи. На нашу думку, доцільніше говорити про модернізацію вже чинних прав 3 урахуванням науковотехнічного прогресу, оскільки всі права, які окремі вчені відносять до четвертого покоління, так чи інакше стосуються особистих прав. Тобто з погляду появи можливості реалізації цих прав їх можна зарахувати й до четвертого покоління, але 3 погляду змістового наповнення - до особистих прав, але в їх модернізованому вигляді.

Звісно деякі з цих прав, як евтаназія, вимагають додаткового міжнародно-правового врегулювання, особливо вважаючи на відсутність одностайності стосовно їх сутнісного наповнення, механізмів реалізації та відповідальності за порушення.

Наприклад, та сама евтаназія в певних видах дозволена лише в 10 країнах, а одностатеві шлюби в 28, в інших зі 193 державахчленах $\mathrm{OOH}$ вони або не передбачені, або прямо заборонені. Таким чином, ці права мають локальний, а не глобальний характер.

Тому чи варто говорити про саме появу принципово нової категорії прав? Наприклад, С. Несинова вважає, що вищезазначені права не можуть бути віднесені до поколінь прав людини, хоча за своєю суттю вони є унікальними й мають бути 
відокремлені та визначені як біологічні (соматичні) права, але вони не можуть набути статусу нового, четвертого покоління прав людини. Біологічні права існують об'єктивно як наслідок факту народження або зачаття людини, відображають його конститутивні ознаки, спрямовані на задоволення потреб, без яких людина не в змозі нормально існувати й розвиватися, виходять 3 природи людини та покликані формувати й підтримувати в людині почуття власної гідності, неповторності, унікальності та індивідуальності [17, с. 40].

Ця точка зору заслуговує на увагу, оскільки біологічні права здебільшого є особистими, тобто наданими людині від природи, питання полягає лише в необхідності їх нормативно-правової регламентації, але одностайності тут немає. На нашу думку, варто звернутися до практики Європейського суду 3 прав людини (далі - ЄСПЛ), який у діяльності з тлумачення Конвенції про основні права і свободи людини та громадянина 1950 p. виходить із принципу ефективного й динамічного тлумачення. Завдяки цьому правотлумачна діяльність ЄСПЛ стає способом не тільки забезпечення й захисту закріплених Конвенцією прав i свобод людини, а й засобом розширення прав і свобод людини та звуження правообмежувальних можливостей держави, що зумовлює розширення правозабезпечувальних обов'язків держави перед людиною. Крім того, принцип ефективного тлумачення дає змогу найкращим чином пристосувати положення Конвенції до соціальних умов, які постійно змінюються. Цей принцип обумовлює так звану «динамічну», або «еволюційну» інтерпретацію конвенційних норм, що застосовується ЄСПЛ [18, с. 134].

Так, суддя ЄСПЛ Дін Шпільман зазначає: «Очевидно, що суть прав і свобод, відображена в Конвенції, не висічена в камені на століття. Вона повинна еволюціонувати в гармонії з юридичним, соціальним і науковим прогресом. Така гнучка інтерпретація конвенції дає змогу збереженим у ній нормам відповідати потребам, які спричиняє складний процес розвитку європейських держав. Іншими словами, суд не може винаходити нові права. Його компетенція - лише модернізувати права, забезпечені Конвенцією та її протоколами» [19].

Як указує I. Суходубова, сутність динамічного тлумачення «полягає в тому, що суб'єкт інтерпретаційної діяльності адаптує правовий акт до тих змін, які відбуваються в суспільних 
Права людини в Україні та у зарубіжних країнах: традиції та новації

відносинах, адже тлумачення норми права не може постійно й назавжди зберігати лише той зміст, який був їй наданий у момент її прийняття» [20, с. 266].

Проблема в тому, що міжнародно-правову регламентацію отримали лише деякі із цих прав, а саме: клонування (Загальна декларація ЮНЕСКО про геном особи та права людини 1997 р., Конвенція про захист прав і гідності людини у зв'язку із застосуванням досягнень біології і медицини (Конвенція про права людини і біомедицину) 1997 р. та Додатковий Протокол до неї стосовно заборони клонування людських істот 1998 р., Декларація $\mathrm{OOH}$ про клонування людини 2005 р.) i трансплантація (Додатковий Протокол до Конвенції про права людини й біомедицину стосовно трансплантації органів і тканин людини 2002 р., Конвенція Р€ проти торгівлі органами людини 2015 p.).

Розглянемо застосування принципу динамічного тлумачення прав, які пропонують віднести до четвертого покоління, на прикладі евтаназії. Стосовно цього права ЄСПЛ уже започаткував практику на підставі тлумачення статті 2 Конвенції 1950 р. Так, Суд уважає, що зі статті 2 Конвенції неможливо вивести право на те, щоб померти як від рук третьої особи, так і за допомогою державного органу. У всіх справах, які він розглядав, Суд наголошував на зобов'язанні держави захищати життя (Pretty проти Сполученого Королівства, § 39).

У справі, яка стосувалася відмови з боку влади надати доступ до препаратів, які дали змогу психічно хворому пацієнту скоїти б самогубство, ЄСПЛ, нагадавши, що Конвенцію потрібно читати як одне ціле, вирішив за необхідне розглянути заяву на підставі статті 8 Конвенції, посилаючись на статтю 2. Суд вирішив, що останнє правове положення зобов'язує державну владу перешкоджати особі вкорочувати собі віку, якщо це рішення не ухвалено добровільно й із повним усвідомленням справи (Haas проти Швейцарії, § 54) [21].

Як ми бачимо, ЄСПЛ уже застосовує принцип динамічного ефективного тлумачення прав, які деякі вчені відносять до четвертого покоління. Можливо, і до більшості прав, які окремі вчені відносять до четвертого покоління, також доцільно застосовувати саме такий підхід, а не виділяти ці права в окрему категорію. Здебільшого всі вони відносяться до особистих i соціально-економічних прав. 
Права людини в Україні та у зарубіжних країнах: традиції та новації

\section{2. Проблеми класифікації четвертого покоління прав людини}

Окрім самого питання існування четвертого покоління прав людини, на окрему увагу заслуговує питання переліку та класифікації цих прав, оскільки це відіграє значну роль при їх подальшій правовій регламентації.

Наприклад, М. Лавриков до соматичних прав відносить право на смерть (евтаназія), права людини щодо іï органів і тканин, сексуальні права, репродуктивні права позитивного (штучне запліднення) та негативного характеру (аборт, стерилізація, контрацепція), право на зміну статі. Під сексуальними розуміється можливість шукати, одержувати й передавати інформацію, що стосується сексуальності, сексуальна освіта, вступ у шлюб, вибір партнера, можливість вирішувати, бути людині сексуально активним чи ні, тощо [22, с. 25]

С. Несинова, навпаки, уважає, що сексуальні права людини не варто виділяти в категорії біологічних прав, а тим більш закріплювати на законодавчому рівні, тому що ці права існують у кожної особи, так би мовити, за умовчанням, тим більше сексуальні права включають права на легалізацію проституції та оборот порнографічної продукції, які в Україні заборонені Кримінальним кодексом (та й у більшості держав - курсив наш). y разі закріплення ї на законодавчому рівні мають застосовуватися державний примус i втручання державних органів, що $\epsilon$ недоречним і безперспективним у цій сфері. Учена переконана, що стосовно сексуальних прав людини держава має захищати ті права, які збігаються з культурними та духовними цінностями певного суспільства й природно відображають розвиток суспільства, створюють умови гідної, правильно орієнтованої політики держави у цій сфері, а альтернативна поведінка (чи вибір у сексуальній сфері) - це власна справа кожного доти, поки це не завдає шкоди іншій людині, групі осіб, суспільству чи держави. У Цивільному кодексі України неодноразово згадуються моральні засади та цінності, інтереси суспільства тощо, що є ще одним обгрунтуванням такої позиції [17, с. 39]. Ми поділяємо цю точку зору, оскільки така фрагментація особистих прав здається хибною.

О. Аврамова й О. Жидкова до четвертого покоління прав людини зараховують більш розширений перелік прав: зміну статі, трансплантацію органів (на засадах законності, справедливості, моральності, добровільності), клонування, 
використання віртуальної реальності, одностатеві шлюби, штучне запліднення, евтаназію, вільну від дитини сім'ю та незалежне від державного втручання життя за релігійними, моральними поглядами [23, с. 104].

I. Жаровська права четвертого покоління поділяє на дві групи. До першої групи, пов'язаної 3 розвитком біомедицини та біотехнологій, генетики, хімії, відносить право на смерть, право на використання репродуктивних технологій, право на аборт і стерилізацію, право на зміну статі, право на терапевтичне клонування, на трансплантацію, право на зміну зовнішності, право на розпорядження своїм тілом після смерті, сексуальні права. До другої групи - новітні права особи в інформаційній сфері [24, c. 23-24].

Н. Болібрух уважає, що до переліку прав четвертого покоління можна включити зміну статі (ЄСПЛ застосовував Європейську конвенцію про захист прав людини та основних свобод у низці важливих рішень, заявивши, що держави повинні надавати трансгендерам можливість пройти хірургічну операцію для повної зміни статі й гендеру та що така хірургічна операція повинна покриватися системою страхування, як «необхідне за медичними показаннями» лікування. Суд також постановив, що держави повинні визнавати зміну статі в документах, що засвідчують особу, трансплантацію органів, клонування, використання віртуальної реальності, одностатеві шлюби (Суд Європейського Союзу прирівняв одностатеві шлюби до традиційних, проте ЄСПЛ не зобов'язав держави-учасниці реєструвати їх), штучне запліднення, евтаназію (ЄСПЛ винесено низку рішень як про відмову в праві на гідну смерть, так і про визнання права на гідну смерть), вільну від дитини сім'ю, незалежне від державного втручання життя за релігійними, моральними поглядами, доступ до Інтернету (Організація Об'єднаних Націй Резолюцією від 3 червня 2011 р. визнала право на доступ до Інтернет одним із невід'ємних прав людини) тощо [25].

У свою чергу, Ю. Дмитрієв до четвертого покоління прав зараховує лише інформаційні права й технології [12, с. 125].

Д. Крилова також наголошує, що четверте покоління не обмежується суто біологічними/соматичними правами, оскільки вони не охоплюють доступ до Інтернету й використання віртуальні права. Ці два права хоча й схожі, але не тотожні. Різниця полягає в тому, що віртуальна реальність не обов'язково 
Права людини в Україні та у зарубіжних країнах: традиції та новації

споживається через доступ до глобальної мережі, тоді як користування мережею Інтернет - це також використання віртуальної реальності. Крім того, використання передбачає виконання дій протягом певного часу, тоді як під доступом мається на увазі сама можливість здійснити певні дії в мережі [26].

Варто згадати про ще про один вид прав, про які говорять юристи-міжнародники, - екологічні права. Н. Мушак із цього приводу зазначає, що нині немає спільної позиції щодо їх правової природи, походження, переліку та місця в системі міжнародно-визнаних прав людини. Міжнародною спільнотою досягнуто консенсусу лише 3 приводу чотирьох видів екологічних прав: право на навколишнє середовище, на доступ до екологічної інформації, на участь суспільства в прийнятті рішень $з$ питань, які стосуються навколишнього середовища, на доступ до правосуддя із цих питань. Але сьогодні поряд із ними виділяють додаткові екологічні права, такі як право на здоров'я, право на доступ до питної води, право власності на природні ресурси. При цьому науковець наголошує на необхідності їх закріплення, як і будь-яких інших прав, що сприятиме розвитку в теорії міжнародного права й доктрини «четвертого покоління» (біологічних прав) i теорії «п'ять поколінь» (наприклад, екологічних прав) [9, с. 300]. 3 останнього твердження можна зробити висновок, що автор усе ж таки до четвертого покоління зараховує біологічні права, а екологічні - в перспективі можуть стати п'ятим поколінням.

У роботі Н. Басалюка та В. Таркіна наводиться цікава класифікація прав четвертого покоління. Так, категорію прав четвертого покоління можна поділити на, по-перше, біологічні права, що пов'язані з розвитком біотехнологій. Вивчення геному людини, генетичні маніпуляції, експерименти з людськими ембріонами, клонування, поява нових термінів («екстракорпоральне запліднення», «генетичний скринінг» тощо) поставили складні юридичні, етичні, моральні й релігійні питання. Це породило необхідність визначення прав, які забезпечуватимуть недоторканність і недоступність людського тіла $з$ його генетичним типом. Зокрема, з'явилися такі права: право на генетичну ідентичність людини, а отже, право на заборону репродуктивного клонування; право людини на визначення меж втручання в генетичну систему клітин і тканин, підпорядковане медичним цілям (біопсія хоріону, амніоцентез 
тощо); право на корекцію статевої належності; право бути донором органів і тканин тощо. До групи біологічних прав можна також віднести право на штучне переривання вагітності, право на смерть за допомогою евтаназії, право на збереження штучного життя мозку після смерті, право на стерилізацію.

По-друге, права людини за ознакою сексуальної орієнтації та сексуальної ідентичності. Перегони дискримінації - основна проблема, 3 якою стикаються трансгендери, транссексуали, інтерсексуали й сексуальні меншини в усьому світі. Тому захисні механізми спрямовані на заборону насильства (від словесних образ і до фізичного насильства), заборону дискримінаційних законів, що можуть використовуватися для переслідування осіб нетрадиційної сексуальної орієнтації чи обмеження їхніх прав на свободу мирних зборів та асоціацій, заборону примусового лікування осіб нетрадиційної сексуальної орієнтації.

На нашу думку, заборона дискримінації за будь-якою ознакою, зокрема ознакою статі, і так детально регламентована як на міжнародному, так і на національному рівнях, а тому недоцільно виділяти їх в окрему групу прав.

По-третє, інформаційні права, пов'язані з появою глобального інформаційного простору. Можна стверджувати, що правовий статус людини як суб'єкта інформаційних відносин грунтується на двох основних правах: 1) право вільно, безперешкодно, на власний розсуд бути суб'єктом інформаційних процесів, шукати, одержувати й поширювати інформацію (це право не пов'язане 3 територіальною юрисдикцією держави та не обмежується територіально державними кордонами); 2) право на захист від неправомірного інформаційного втручання, яке включає право на конфіденційність інформації про особисте життя, конфіденційність кореспонденції, захист від розповсюдження неправдивої інформації, що завдає шкоди честі й репутації особи $[27$, c. 34].

На нашу думку, якраз інформаційні або віртуальні права $\epsilon$ менш спірними, оскільки є відображенням реалій сьогодення. Але право на доступ до Інтернету в епоху віртуальних технологій не можна вважати чимось новим, це те саме право на свободу слова, пристосоване під сучасні реалії, де майже всі сфери суспільного життя - робота, навчання, стосунки, фінанси, торгівля, відпочинок - перейшли до нового виміру, хоча варто зазначити, що в багатьох країнах, як і в Україні, ця сфера 
Права людини в Україні та у зарубіжних країнах: традиції та новації

недостатньо врегульована на законодавчому рівні й на міжнародному. Тому ми вважаємо, що ці права й акти щодо них мають бути переглянуті та ретельно досліджені як із теоретичної, так і з практичної точок зору.

Таким чином, можна стверджувати, що незалежно від прихильності до тієї чи іншої назви четвертого покоління прав майже одноголосно до цієї категорії прав відноситься право на смерть, трансплантація, зміна статі, тобто так звані біологічні права. Однак погодимося з М. Тиріною, що не можна говорити, що такі права з'явилися тільки сьогодні, в умовах розвитку генетичних, медико-біологічних експериментів, що ці права притаманні безпосередньо людині нового покоління в сучасній державі. Навпаки, ці права належать до природних, ідея яких виникла в Голландії ще в XVIII ст. [28, с. 731].

Різноманітність поглядів свідчить про невизначеність світової юридичної науки щодо системи прав людини. Як слушно зазначає М. Тиріна, деякі із зазначених підходів $\epsilon$ занадто вузькими, деякі - не відповідають сьогоднішнім умовам розвитку суспільства, інші - поєднують права третього покоління 3 четвертим. Тому вона пропонує як четверте покоління прав виділити біологічні права людини та громадянина [28, с. 730].

Можна погодитися з С. Несиновою, яка зазначає, що, перш ніж говорити про нові права людини, необхідно повною мірою науково дослідити, як будуть відбиватися нові можливості людей, чи варто ці можливості називати правами людини, чи визнавати їх державою як найважливішу цінність, як це вплине на подальше існування та розвиток суспільства й людства загалом [17, с. 39].

Отже, усі права, які відносяться до першого, другого і третього поколінь, знайшли своє правове закріплення як на міжнародному, так і на державному рівнях тією чи іншою мірою. І дискусії стосовно їх переліку хоча й точаться, але не є критичними, відбуваються більше в науковій сфері, ніж у практичній площині. Якщо говорити про так зване четверте покоління прав людини, то більшість науковців усе ж таки поділяє думку його становлення, але кардинально розходяться в переліку цих прав, що $є$ цілком природним, оскільки ці права знаходяться на стадії свого становлення й нормативно-правого закріплення. I хоча деякі з них, наприклад, інформаційні права, клонування, уже закріплено на міжнародному рівні, але або в необов'язкових актах, або локально. Тому ці права й акти щодо них мають бути переглянуті та ретельно 
Права людини в Україні та у зарубіжних країнах: традиції та новації

досліджені як із теоретичної, так і з практичної точок зору з урахуванням вимог сучасності.

Що стосується наміру нормативно-правової регламентації так званих біологічних прав, то тут складно досягти консенсусу через етичні, культурні, моральні й релігійні причини. Зокрема, право на клонування людини, уживання наркотичних i психотропних засобів прямо заборонено в більшості країн світу. До евтаназії, абортів і зміни статі негативно ставляться різні конфесії. Право розпоряджатися своїми органами і тканинами взагалі може призвести до торгівлі людьми й органами. Як слушно зауважив В. Сердуніч, якщо всі вказані права будуть визнані правомірними й нормативно регламентовані, це може призвести до пропаганди такої поведінки в суспільстві; на цьому можна заробляти великі гроші; звуження значення держави як організації суспільства; утрати моральних особливостей цивілізації як окремого своєрідного світового явища; законодавчого закріплення розриву між релігійною, моральною та правовою нормами, що може спричинити правовий нігілізм [29]. Дійсно, специфіка нового покоління прав у тому, що їх передчасна міжнародно-правова регламентація без грунтовного всебічного дослідження може спричинити незворотні негативні наслідки для існування всього людства.

\section{Висновки}

Таким чином, можна констатувати, що питання становлення і змістового наповнення четвертого покоління прав людини $€$ дискусійним. Це пов'язано як із критикою самої системи класифікації на підставі історичних етапів розвитку, так і 3 різноманіттям думок учених із цього приводу.

Можна погодитися з думкою таких українських науковців, як В. Мицик і В. Буткевич, що ця класифікація $є$ умовно виведеною та не відповідає практиці прийняття міжнародних договорів 3 прав людини. Така категорія, як права людини, є динамічною, чутливо реагує на зміни в суспільстві, пристосовується до потреб людини, тому класифікація за етапами історичного розвитку не $\epsilon$ досконалою.

Звісно, певна класифікація прав потрібна, що полегшує їх нормативно-правове забезпечення й реалізацію, дасть змогу узгодити позицію міжнародного співтовариства стосовно змістового наповнення цих прав. Але тут вистачить і класичного 
Права людини в Україні та у зарубіжних країнах: традиції та новації

поділу прав за сферами суспільного життя. Це здається доречним i зважаючи на відсутність одностайності науковців щодо виокремлення та класифікації четвертого покоління прав.

Так, пропонуються такі назви прав, як біологічні, соматичні, віртуальні. Як ми бачимо, перелік прав, віднесених до четвертого покоління, також неоднорідний. Виокремлення сексуальних та інформаційних прав узагалі викликає сумніви через нерозривність їх із особистими правами, які притаманні людині від народження, а сучасні технології дали змогу лише розкрити ці права з нового ракурсу.

Таким чином, незалежно від прихильності до тієї чи іншої назви четвертого покоління прав майже одноголосно до цієї категорії прав відноситься право на смерть, трансплантацію, зміну статі, тобто вузький перелік так званих біологічних прав. Розширення цих прав за рахунок сексуальних чи права на сім'ю без дитини вважається неправильним. Перш ніж говорити про появу революційно нових права людини, варто визначитися, чи варто нові можливості, які стали доступними завдяки науково-технічному прогресу називати правами людини, піддавати їх правовій регламентації та як це вплине на подальше існування й розвиток людства.

По суті, усі права, віднесені до четвертого покоління, окрім деяких біологічних, $є$ модифікованим проявом особистих прав, закріплених у багатьох міжнародних правових актах. Тому доречним уважається застосування до деяких із цих прав принципу динамічного й ефективного тлумачення, який успішно використовує ЄСПЛ при розгляді справ і тлумаченні Конвенції, прийнятої більше ніж півстоліття тому! А відповідні міжнародні акти мають бути переглянуті та модифіковані з урахуванням викликів сучасності.

Звісно, ці права потребують подальших наукових досліджень, проте їх правова регламентація здається складним і тривалим процесом через етичні, культурні, моральні та релігійні причини. Специфіка нового покоління прав у тому, що їх міжнародноправова регламентація може спричинити незворотні негативні наслідки для існування всього людства.

\section{Список використаних джерел:}

1. Бахин С.В. О классификации прав человека, провозглашённых в международных соглашениях. Правоведение. 1991. № 2. C. 41-51. 
Права людини в Україні та у зарубіжних країнах: традиції та новації

2. Капицын В.М. История, теория и защита прав человека : учебник. Москва : Московский университет потребительской кооперации, 2003. 260 с. С. 160.

3. Околіт Т. Класифікація прав людини та її критерії. Юридичний вісник України. 2002. № 52. С. 10.

4. Vasak K. Les problemes specificues de la mise en oeuvre des droits economiques et sociaux de l'homme. Louvain. Universite catholique de Centre d?etudes europeennes. Vers une protection efficace des droits economiques et sociaux. Deuxieme colloque de Departament des droits de l'homme. Louvian, Vander, 1973. P. 11-34.

5. Поленина С.В. Права женщин в системе прав человека: международный и национальный аспект. Москва : Ин-т государства и права РАН, 2000. С. 9.

6. Vasak K. Les Différentes catégories des droits de l'homme, in A. Lapeyre. Les dimensions universelles des droits de l'homme. 1990. Vol. 1. P. 303.

7. Іванків І.Б. Відмінні ознаки прав людини третього покоління. Наукові записки НаУКМА. 2016. Том 181. С. 54-57.

8. Буткевич В.Г. Класифікація прав людини. Міжнародне право. Основні галузі. Київ : Либідь, 2004. С. 206-208.

9. Мушак Н.Б. Концептуальні підходи до класифікації прав людини в умовах глобалізаційних процесів. Часопис Київського університету права. 2011. № 2. С. 298-301.

10. Корельский В.М. Теория государства и права : учебник для вузов / под ред. проф. В.М. Корельского и проф. В.Д. Перевалова. Москва : НОРМА-ИНФРА-М, 2000. 616 с.

11. Крусс В.И. Личностные («соматические») права человека в конституционном и философско-правовом измерении: к постановке проблемы. Государство и право. Москва : Наука. 2000. № 10. С. 43-50.

12. Головистикова А.Н., Грудцына Л.Ю. Права человека : учебник. Москва : Эксмо, 2008. 327 с.

13. Венгеров А.Б. Теория государства и права : учебник для юридических вузов. Москва : Юриспруденция, 2000. 478 с.

14. Хажинський Р.М. Соматичні права людини: становлення та сучасний стан. Право і суспільство. 2015. № 6-2. С. 35-39. URL: http://pravoisuspilstvo.org.ua/archive/2015/6_2_2015/part_2/9.pdf.

15. Ковлер А.И. Антропология права : учебник. Москва, 2002. $480 \mathrm{c}$. 
16. Ивентьев С.И. Классификация прав и свобод человека и гражданина. Казанская наука. 2010. № 3. С. 199-203.

17. Несинова С.В., Князєва Ю.С. Нове покоління прав людини: сучасні проблеми класифікації. Вісник Дніпропетровського університету імені Альфреда Нобеля. Серія «Юридичні науки». 2015. № 2 (7). С. 36-42.

18. Тлумачення та застосування Конвенції про захист прав людини й основоположних свобод Європейським судом з прав людини та судами України : навчальний посібник / М.В. Мазур, С.Р. Тагієв, А.С. Беніцький, В.В. Кострицький ; відп. ред. В.М. Карпунов. Луганськ : РВВ ЛДУВС, 2006. 600 с.

19. Лакеева Е. Правила жизни Дина Шпильмана. URL: http://pravo.ru/story/view/102097/.

20. Суходубова I.В. Динамічне тлумачення як засіб адаптації текстуальної форми законодавства до змін суспільних відносин. Вісник Національного університету "Юридична академія України імені Ярослава Мудрого». 2014. № 2. С. 264-272.

21. Дроздов О., Дроздова О. Евтаназія у правовому вимірі: чи має людина право на самовизначення шляхом смерті. URL: https://www.echr.com.ua/evtanaziya-u-pravovomu-vimiri-chi-mayelyudina-pravo-na-samoviznachennya-shlyaxom-smerti/\#: : text=Так\%20активна\%20евтаназія\%20легалізована\%20в,загаль ного\%20законодавства\% $20 \mathrm{i} \% 20$ судових $\% 20$ прецедентів.

22. Лаврик М.А. К теории соматических прав человека. Сибирский юридический вестник. Иркутск : Юридический институт ИГУ. 2005. № 3. С. 23-33.

23. Аврамова О., Жидкова О. Четверте покоління прав людини: постановка проблеми. Право України. 2010. № 2. C. 101-107.

24. Жаровська I.M. Четверте покоління прав людини: до проблем узагальненої класифікації. Вісник Львівського торговельно-економічного університету. Серія «Юридичні науки». 2018. Вип. 7. С. 19-25.

25. Болібрух Н.Б. Класифікація прав людини за Карелом Васаком. URL: http://ena.lp.edu.ua:8080/bitstream/ntb/ 28029/1/042_160_163.pdf.

26. Крилова Д. Четверте покоління прав людини в контексті взаємозв'язку правових та моральних норм. National law journal: theory and practice. $2017 . \quad$ URL: http://www.jurnaluljuridic.in.ua/archive/2017/2/6.pdf. 
27. Басалюк Н.В., Таркін В.П. Історія твориться сьогодні: становлення четвертого покоління прав людини. Прикарпатський юридичний вісник. 2018. Випуск 1 (22). С. 33-37.

28. Тиріна М.. Покоління прав людини: проблеми сучасної класифікації. Держава і право. 2011. Випуск 52. С. 728-732.

29. Сердуніч В.К. Четверте покоління прав людини в контексті взаємозв'язку правових та моральних норм. International Electronic Scientific Journal «Science Online». URL: https://nauka-online.com/wpcontent/uploads/2019/06/Serdunich.pdf. 